\title{
Growth of Chrysanthemum Explants on MS Medium Sterilized by Disinfectants and Essential Oils
}

\author{
Wittaya Deein, Chockpisit Thepsithar, Aree Thongpukdee, and Suppaya Tippornwong
}

\begin{abstract}
A sterile condition of culture medium is one of the main aspects for micropropagation. The alternative technique for medium sterilization to replace autoclaving was carried out. For sterilization of Murashige and Skoog (MS) medium, commercial essential oils, disinfectants or in combinations were tested. Each essential oil or disinfectant or combination was added to a $20-\mathrm{mL}$ medium in a $120-\mathrm{mL}$ container, kept for 2 weeks before evaluating sterile conditions. Treated media were compared to control medium, autoclaved at 121 degree Celsius for $15 \mathrm{~min}$. Sterile conditions of MS medium were found $100 \%$ from $10 \%$ povidone-iodine $(108 \mu \mathrm{L}), 6 \%$ sodium hypochlorite $(36 \mu \mathrm{L}), 2 \%$ iodine $+2.4 \%$ potassium iodide $(36 \mu \mathrm{L})$, while $95 \%$ sterile conditions were obtained from $2 \%$ iodine $+\mathbf{2 . 4 \%}$ potassium iodide in combination with $10 \%$ povidone-iodine (ratio $1: 1$ at $36 \mu \mathrm{L}$ and ratio $1: 3$ at $72 \mu \mathrm{L}$ ), $10 \%$ povidone-iodine in combination with lemon oil (ratio $3: 1,108$ $\mu \mathrm{L})$ compared to $100 \%$ sterile conditions from autoclaved medium. Effects of these treated media on growth of chrysanthemum shoot and node explants were investigated. It was found that growth of explants on medium treated with $10 \%$ povidone-iodine or $2 \%$ iodine $+\mathbf{2 . 4 \%}$ potassium iodide alone or in combination with $10 \%$ povidone-iodine (ratio $1: 1$ ) or $6 \%$ sodium hypochlorite was comparable to those on autoclaved medium.
\end{abstract}

Index Terms-MS medium, chrysanthemum, disinfectants, essential oils, sterilization, plant tissue culture.

\section{INTRODUCTION}

Plant tissue culture is an effective technique for plant micropropagation by using many parts of plants such as cells, tissues and organs, cultured on synthetic medium under sterile conditions. Unfortunately, most agriculturists cannot carry out plant tissue culture laboratory by themselves due to high production costs. One of the major problems is expensive equipment especially an autoclave, a sterilizing apparatus. Therefore, the development of techniques, using chemicals or plant extracts or in combinations for sterilizing culture medium, to replace the autoclaving method for establishing aseptic culture medium will be the optional procedure for plant tissue culture.

The use of disinfectants, fungicides, bactericides and biocides such as sodium hypochlorite, calcium hypochlorite, chlorine, methylchloroisothaiazolinone, hydrogen peroxide,

Manuscript received May 7, 2013; revised July 15, 2013. This work was supported in part by Toray Science Foundation (TTSF) and Faculty of Science, Silpakorn University, Thailand.

W. Deein, C. Thepsithar, A. Thongpukdee, and S. Tippornwong are with the Biology Department, Faculty of Science, Silpakorn University, Nakhon Pathom 73000, Thailand (e-mail: deein_w_su@hotmail.com, tchockpis@gmail.com, chockpis@su.ac.th, toh25@ hotmail.com, ong_kid@ hotmail.com). and chemical mixtures containing methylisothiazolinone, magnesium chloride, magnesium nitrate, potassium sorbate and sodium benzoate supplemented in culture medium for preventing contamination was reported [1], [2]. Sterile culture media without autoclaving of some plants using sodium hypochlorite for sugarcane micropropagation [3] and sodium hypochlorite or sodium dichloroisocyanurate for orchid cultures [4]-[7] were established. Moreover, the studies on plant extracts and essential oils as microorganism inhibitors were also presented on clove (Eugenia caryophyllata Thunb.) [8], [9], lemon [Citrus limon (L.) Burm. F.] [10], [11], cinnamon (Cinnamomum zeylanicum Breyne) [12]-[14], betel (Piper betle L.) [15]-[17], cassumunar ginger (Zingiber cassumunar Roxb.) [18], holy basil (Ocimum sanctum L.), lavender (Lavandula angustifolia Mill.) [19], [20], bergamot (C. bergamia Risso) [21], and turmeric (Curcuma longa L.) [22].

This research reported effects of disinfectants and essential oils as sterilizing agents on sterile conditions of MS medium and growth of chrysanthemum shoot and node explants on treated medium.

\section{MATERIALS AND METHODS}

\section{A. Medium Used}

The medium used for in vitro culture of chrysanthemum nodes was Murashige and Skoog (MS) medium [23] supplemented with $30 \mathrm{~g} / \mathrm{L}$ sucrose and $5.5 \mathrm{~g} / \mathrm{L}$ agar (Hardy Diagnostics Criterion agar, Bacteriological grade, USA). The $\mathrm{pH}$ of the medium was adjusted to 5.8. Each essential oil (cinnamon oil, clove oil, and lemon oil) or disinfectant [2\% iodine $+2.4 \%$ potassium iodide $(\mathrm{KI}), 10 \%$ povidone-iodine and $6 \%$ sodium hypochlorite $(\mathrm{NaOCl})]$ or combination was added in a $120-\mathrm{mL}$ glass jar containing $20 \mathrm{~mL}$ of culture medium in various concentrations $(9-180 \mu \mathrm{L})$. All media were kept in room temperature $\left(29 \pm 2^{\circ} \mathrm{C}\right)$ for 2 weeks before investigating effects of sterilizing agents on sterile conditions of media compared to autoclaved medium. Numbers of containers containing culture medium that obtained totally sterile condition were collected. Sterilizing agents added in medium providing $95-100 \%$ sterile conditions were chosen for culturing shoot and node explants of chrysanthemum 'Moneymaker Improved', about $1 \mathrm{~cm}$. long with 2 nodes, for 4 and 6 weeks, respectively.

\section{B. Culture Conditions}

All cultures were incubated under a $25 \pm 1^{\circ} \mathrm{C}$ with a $16 \mathrm{~h}$ photoperiod at $35-40 \mu \mathrm{mole} \cdot \mathrm{m}^{-2} \mathrm{~s}^{-1}$ provided by cool white lights. 


\section{Statistical Analysis}

Sterile conditions of media were evaluated after 2 weeks with 20 replications. Growth of chrysanthemum shoots from shoot and node explants, whole fresh weight (FW), shoot length, root length and number of node, were collected after 4 and 6 weeks of culturing, respectively. Each treatment was replicated 10 times. The completely randomized design (CRD) was used as the experimental design and means were compared by Duncan's New Multiple Range Test (DMRT) at $P=0.05[24]$.

\section{RESULTS}

\section{A. Effects of Sterilizing Agents on Sterile Conditions of Treated Media}

A 20-mL MS medium was treated with each sterilizing agent, kept in room temperature (about $29 \pm 2{ }^{\circ} \mathrm{C}$ ) for 2 weeks For MS medium, $95-100 \%$ sterile conditions of culture medium was found from medium supplemented with clove oil at $9 \mu \mathrm{L} / 20 \mathrm{~mL}$ medium, cinnamon oil, $2 \%$ iodine $+2.4 \%$ $\mathrm{KI}$, or $6 \% \mathrm{NaOCl}$ at $36 \mu \mathrm{L} / 20 \mathrm{~mL}$ medium, and $10 \%$ povidone-iodine at $108 \mu \mathrm{L} / 20 \mathrm{~mL}$ medium. For sterilizing agents in combinations, $95-100 \%$ sterile conditions of culture medium was found from medium supplemented with $2 \%$ iodine $+2.4 \% \mathrm{KI}: 10 \%$ povidone-iodine $(1: 1)$ at 36 $\mu \mathrm{L} / 20 \mathrm{~mL}$ medium, $2 \%$ iodine $+2.4 \% \mathrm{KI}: 10 \%$ povidoneiodine $(1: 3)$ or $2 \%$ iodine $+2.4 \% \mathrm{KI}:$ clove oil at $72 \mu \mathrm{L} / 20$ $\mathrm{mL}$ medium, $2 \%$ iodine $+2.4 \% \mathrm{KI}$ : cinnamon oil $(6: 1)$ or $10 \%$ povidone-iodine : lemon oil $(3: 1)$ at $108 \mu \mathrm{L} / 20 \mathrm{~mL}$ medium (Table I).

TABLE I: PERCENTAGE OF STERILE MS MEDIUM AFTER TREATED WITH DIFFERENT ESSENTIAL OILS, DISINFECTANTS, AND COMBINATIONS FOR 2 WEEKS

\begin{tabular}{|c|c|c|c|c|c|c|}
\hline \multirow{3}{*}{ Treatment } & \multicolumn{6}{|c|}{ Sterile condition $(\%)^{1}$} \\
\hline & \multicolumn{6}{|c|}{ Concentration $(\mu \mathrm{L})$ in a $20-\mathrm{mL}$ MS } \\
\hline & 9 & 18 & 36 & 72 & 108 & 180 \\
\hline Autoclaved (control) & \multicolumn{6}{|c|}{100} \\
\hline Cinnamon oil (A) & 35 & 40 & 100 & 100 & 100 & 100 \\
\hline Clove oil (B) & 95 & 100 & 100 & 100 & 100 & 100 \\
\hline Lemon oil (C) & 45 & 45 & 60 & 70 & 80 & 90 \\
\hline $2 \%$ Iodine $+2.4 \% \mathrm{KI}(\mathrm{D})$ & - & - & 100 & 100 & 100 & 100 \\
\hline $10 \%$ Povidone-iodine $(\mathrm{E})$ & - & - & 85 & 95 & 100 & 100 \\
\hline $6 \% \mathrm{NaOCl}(\mathrm{F})$ & - & - & 100 & 100 & 100 & 100 \\
\hline $\mathrm{D}: \mathrm{E}(1: 1)$ & - & - & 95 & 100 & 100 & 100 \\
\hline $\mathrm{D}: \mathrm{E}(1: 3)$ & - & - & 55 & 95 & 100 & 100 \\
\hline $\mathrm{D}: \mathrm{A}(6: 1)$ & - & - & 75 & 85 & 100 & 100 \\
\hline $\mathrm{D}: \mathrm{B}(6: 1)$ & - & - & 50 & 95 & 100 & 100 \\
\hline $\mathrm{D}: \mathrm{C}(3: 1)$ & - & - & 45 & 50 & 55 & - \\
\hline $\mathrm{E}: \mathrm{A}(6: 1)$ & - & - & 45 & 55 & 80 & - \\
\hline $\mathrm{E}: \mathrm{B}(6: 1)$ & - & - & 25 & 50 & 70 & - \\
\hline $\mathrm{E}: \mathrm{C}(3: 1)$ & - & - & 30 & 75 & 95 & 100 \\
\hline
\end{tabular}

${ }^{1} n=20 ;-=$ not available

\section{B. Effects of Sterilizing Agent-Treated Media on Growth of Chrysanthemum Explants}

Medium supplemented with clove oil and cinnamon oils (9 and $36 \mu \mathrm{L} / 20 \mathrm{~mL}$ medium), disinfectants (36 and $108 \mu \mathrm{L} / 20$
$\mathrm{mL}$ medium), and combinations $(36,72$, and $108 \mu \mathrm{L} / 20 \mathrm{~mL}$ medium) that gave $95-100 \%$ sterile conditions of medium were chosen for culturing chrysanthemum shoot and node explants.

For growth of shoot explants, autoclaved medium provided $536.2 \mathrm{mg}$. FW, $3.12 \mathrm{~cm}$. shoot length, $3.57 \mathrm{~cm}$. root length, and 8.1 nodes (Fig. 1 a) ). For disinfectants alone, $2 \%$ iodine $+2.4 \%$ potassium iodide and $6 \% \mathrm{NaOCl}$ at $36 \mu \mathrm{L} / 20$ $\mathrm{mL}$ medium obtained 311.8 and $229.3 \mathrm{mg}$. FW, 2.26 and 1.54 $\mathrm{cm}$. shoot length, 4.11 and $5.31 \mathrm{~cm}$. root length, 7.4 and 5.2 nodes, respectively (Fig. 1 b) and 1 d) ). However, $10 \%$ povidone-iodine at $108 \mu \mathrm{L} / 20 \mathrm{~mL}$ medium gave the best results providing $555.6 \mathrm{mg}$. $\mathrm{FW}, 2.77 \mathrm{~cm}$. shoot length, 5.73 $\mathrm{cm}$. root length, and 7.4 nodes (Fig. $1 \mathrm{c}$ ) ). For combinations of disinfectants, $2 \%$ iodine $+2.4 \% \mathrm{KI}: 10 \%$ povidone-iodine $(1: 1)$ at $36 \mu \mathrm{L} / 20 \mathrm{~mL}$ medium and $2 \%$ iodine $+2.4 \% \mathrm{KI}$ : $10 \%$ povidone-iodine $(1: 3)$ at $72 \mu \mathrm{L} / 20 \mathrm{~mL}$ medium provided 250.5 and $191.3 \mathrm{mg}$. FW, 1.92 and $1.39 \mathrm{~cm}$. shoot length, 5.43 and $3.22 \mathrm{~cm}$. root length, 8.3 and 7.4 nodes, respectively (Fig. 1 e) and Fig. 1 f) ). A combination of disinfectant and essential oil, $10 \%$ povidone-iodine : lemon oil $(3: 1)$ at $108 \mu \mathrm{L} / 20 \mathrm{~mL}$ medium, gave $182.3 \mathrm{mg}$. FW, $1.24 \mathrm{~cm}$. shoot length, $2.78 \mathrm{~cm}$. root length, and 6.5 nodes (Fig. $1 \mathrm{~g}$ ) ). In other treated media, no growth was found and explants died eventually (Table II).

\begin{tabular}{|c|c|c|c|c|c|}
\hline \multicolumn{2}{|c|}{$\begin{array}{l}\text { Treatment in } \\
20 \mathrm{~mL} \text { medium } \\
\end{array}$} & \multicolumn{4}{|c|}{ Growth of chrysanthemum shoot ${ }^{2}$} \\
\hline $\begin{array}{l}\text { Sterilizing } \\
\text { agents }{ }^{1}\end{array}$ & $\mu \mathrm{L}$ & $\begin{array}{l}\text { Fresh weight } \\
(\mathrm{g})\end{array}$ & $\begin{array}{l}\text { Shoot length } \\
(\mathrm{cm})\end{array}$ & $\begin{array}{l}\text { Root length } \\
(\mathrm{cm})\end{array}$ & $\begin{array}{c}\text { No. of } \\
\text { node }\end{array}$ \\
\hline Autoclaved & 0 & $536.2 \pm 30.3 \mathrm{~b}$ & $3.12 \pm 0.03 \mathrm{a}$ & $3.57 \pm 0.09 \mathrm{e}$ & $8.1 \pm 0.1 \mathrm{a}$ \\
\hline A & 36 & $0.0 \pm 0.0 \mathrm{~h}$ & $0.00 \pm 0.00 \mathrm{~g}$ & $0.00 \pm 0.00 \mathrm{~h}$ & $0.0 \pm 0.0 \mathrm{e}$ \\
\hline$B$ & 9 & $0.0 \pm 0.0 \mathrm{~h}$ & $0.00 \pm 0.00 \mathrm{~g}$ & $0.00 \pm 0.00 \mathrm{~h}$ & $0.0 \pm 0.0 \mathrm{e}$ \\
\hline D & 36 & $311.8 \pm 17.0 \mathrm{c}$ & $2.26 \pm 0.06 \mathrm{c}$ & $4.11 \pm 0.07 \mathrm{~d}$ & $7.4 \pm 0.1 \mathrm{~b}$ \\
\hline$E$ & 108 & $555.6 \pm 9.3 \mathrm{a}$ & $2.77 \pm 0.03 \mathrm{~b}$ & $5.73 \pm 0.03 \mathrm{a}$ & $7.4 \pm 0.1 \mathrm{~b}$ \\
\hline 4 & 36 & $229.3 \pm 5.8 \mathrm{~d}$ & $1.54 \pm 0.03 \mathrm{e}$ & $5.31 \pm 0.03 \mathrm{c}$ & $5.2 \pm 0.1 \mathrm{~d}$ \\
\hline $\mathrm{D}: \mathrm{E}(1: 1)$ & 36 & $250.5 \pm 10.3 \mathrm{e}$ & $1.92 \pm 0.06 \mathrm{~d}$ & $5.43 \pm 0.03 \mathrm{~b}$ & $8.3 \pm 0.1 \mathrm{a}$ \\
\hline $\mathrm{D}: \mathrm{E}(1: 3)$ & 72 & $191.3 \pm 7.7 \mathrm{f}$ & $1.39 \pm 0.03 \mathrm{f}$ & $3.22 \pm 0.03 \mathrm{f}$ & $7.4 \pm 0.1 \mathrm{~b}$ \\
\hline $\mathrm{D}: \mathrm{A}(6: 1)$ & 108 & $0.0 \pm 0.0 \mathrm{~h}$ & $0.00 \pm 0.00 \mathrm{~g}$ & $0.00 \pm 0.00 \mathrm{~h}$ & $0.0 \pm 0.0 \mathrm{e}$ \\
\hline $\mathrm{D}: \mathrm{B}(6: 1)$ & 72 & $0.0 \pm 0.0 \mathrm{~h}$ & $0.00 \pm 0.00 \mathrm{~g}$ & $0.00 \pm 0.00 \mathrm{~h}$ & $0.0 \pm 0.0 \mathrm{e}$ \\
\hline $\mathrm{E}: \mathrm{C}(3: 1)$ & 108 & $182.3 \pm 11.1 \mathrm{~g}$ & $1.24 \pm 0.03 \mathrm{f}$ & $2.78 \pm 0.07 \mathrm{~g}$ & $6.5 \pm 0.1 \mathrm{c}$ \\
\hline
\end{tabular}

For growth of nodes explants, autoclaved medium provided $446.7 \mathrm{mg}$. FW, $3.47 \mathrm{~cm}$. new shoot length, $6.43 \mathrm{~cm}$. root length, and 7.3 nodes (Fig. 2 a) ), while clove oil at 9 $\mu \mathrm{L} / 20 \mathrm{~mL}$ medium gave $88.7 \mathrm{mg}$. FW, $0.67 \mathrm{~cm}$. new shoot length, and 5.3 nodes (Fig. 2 b) ), and $2 \%$ iodine $+2.4 \% \mathrm{KI}$ and $6 \% \mathrm{NaOCl}$ at $36 \mu \mathrm{L} / 20 \mathrm{~mL}$ medium obtained 314.7 and $387.7 \mathrm{mg}$. FW, 2.10 and $2.40 \mathrm{~cm}$. new shoot length, 7.47 and $5.63 \mathrm{~cm}$. root length, 7.7 and 8.0 nodes, respectively (Fig. $2 \mathrm{c}$ ) and Fig. 2 e) ). However, $10 \%$ povidone-iodine at $108 \mu \mathrm{L} / 20$ $\mathrm{mL}$ medium gave the best results obtaining $597.3 \mathrm{mg}$. FW, $3.40 \mathrm{~cm}$. new shoot length, $7.87 \mathrm{~cm}$. root length, and 9.0 nodes (Fig. 2 d) ). 
In addition, for growth of node explants on medium added with each of a combination of sterilizing agents, $2 \%$ iodine + $2.4 \% \mathrm{KI}: 10 \%$ povidone-iodine $(1: 1)$ at $36 \mu \mathrm{L} / 20 \mathrm{~mL}$ medium and $2 \%$ iodine $+2.4 \% \mathrm{KI}: 10 \%$ povidone-iodine $(1$ : 3) at $72 \mu \mathrm{L} / 20 \mathrm{~mL}$ medium gave 456.0 and $311.3 \mathrm{mg}$. FW, 2.73 and $1.93 \mathrm{~cm}$. new shoot length, 7.83 and $7.37 \mathrm{~cm}$. root length, 8.3 and 7.3 nodes, respectively (Fig. 2 f) and Fig. 2 g) ). Whist, $10 \%$ povidone-iodine : lemon oil (3:1) at 108 $\mu \mathrm{L} / 20 \mathrm{~mL}$ medium gave $246.7 \mathrm{~g}$. FW, $1.40 \mathrm{~cm}$. new shoot length, $7.33 \mathrm{~cm}$. root length, and 6.7 nodes (Fig. $2 \mathrm{~h}$ ) ). In other treated media, the same results as shoot growth were obtained. No growth was found and explants died (Table III).

\begin{tabular}{|c|c|c|c|c|c|}
\hline \multicolumn{2}{|c|}{$\begin{array}{l}\text { Treatment in } \\
20 \mathrm{~mL} \text { medium }\end{array}$} & \multicolumn{4}{|c|}{ Growth of chrysanthemum shoot ${ }^{2}$} \\
\hline $\begin{array}{l}\text { Sterilizing } \\
\text { agents }{ }^{1}\end{array}$ & $\mu \mathrm{L}$ & $\begin{array}{c}\text { Fresh weight } \\
(\mathrm{g})\end{array}$ & $\begin{array}{l}\text { Shoot length } \\
(\mathrm{cm})\end{array}$ & $\begin{array}{l}\text { Root length } \\
(\mathrm{cm})\end{array}$ & $\begin{array}{c}\text { No. of } \\
\text { node }\end{array}$ \\
\hline Autoclaved & 0 & $446.7 \pm 17.1 \mathrm{~b}$ & $3.47 \pm 0.12 \mathrm{a}$ & $6.43 \pm 0.15 c$ & $7.3 \pm 0.3 \mathrm{bc}$ \\
\hline A & 36 & $0.0 \pm 0.0 \mathrm{f}$ & $0.00 \pm 0.00 \mathrm{f}$ & $0.00 \pm 0.00 \mathrm{f}$ & $0.0 \pm 0.0 \mathrm{~d}$ \\
\hline B & 9 & $88.7 \pm 2.9 \mathrm{f}$ & $0.67 \pm 0.03 \mathrm{f}$ & $0.00 \pm 0.00 \mathrm{f}$ & $5.3 \pm 0.0 \mathrm{~d}$ \\
\hline $\mathrm{D}$ & 36 & $314.7 \pm 7.5 \mathrm{~d}$ & $2.10 \pm 0.12 \mathrm{~d}$ & $7.47 \pm 0.18 \mathrm{ab}$ & $7.7 \pm 0.3 \mathrm{bc}$ \\
\hline $\mathrm{E}$ & 108 & $597.3 \pm 30.3 \mathrm{a}$ & $3.40 \pm 0.10 \mathrm{a}$ & $7.87 \pm 0.18 \mathrm{a}$ & $9.0 \pm 0.6 \mathrm{a}$ \\
\hline $\mathrm{F}$ & 36 & $387.7 \pm 9.7 \mathrm{c}$ & $2.40 \pm 0.12 \mathrm{c}$ & $5.63 \pm 0.12 \mathrm{~d}$ & $8.0 \pm 0.0 \mathrm{ab}$ \\
\hline $\mathrm{D}: \mathrm{E}(1: 1)$ & 36 & $456.0 \pm 13.9 \mathrm{~b}$ & $2.73 \pm 0.03 \mathrm{~b}$ & $7.83 \pm 0.03 \mathrm{a}$ & $8.3 \pm 0.3 \mathrm{ab}$ \\
\hline $\mathrm{D}: \mathrm{E}(1: 3)$ & 72 & $311.3 \pm 6.4 \mathrm{~d}$ & $1.93 \pm 0.09 \mathrm{~d}$ & $7.37 \pm 0.15 b$ & $7.3 \pm 0.3 \mathrm{bc}$ \\
\hline $\mathrm{D}: \mathrm{A}(6: 1)$ & 108 & $0.0 \pm 0.0 \mathrm{f}$ & $0.00 \pm 0.00 \mathrm{f}$ & $0.00 \pm 0.00 \mathrm{f}$ & $0.0 \pm 0.0 \mathrm{~d}$ \\
\hline $\mathrm{D}: \mathrm{B}(6: 1)$ & 72 & $0.0 \pm 0.0 \mathrm{f}$ & $0.00 \pm 0.00 \mathrm{f}$ & $0.00 \pm 0.00 \mathrm{f}$ & $0.0 \pm 0.0 \mathrm{~d}$ \\
\hline $\mathrm{E}: \mathrm{C}(3: 1)$ & 108 & $246.7 \pm 4.1 \mathrm{e}$ & $1.40 \pm 0.06 \mathrm{e}$ & $7.33 \pm 0.12 b$ & $6.7 \pm 0.3 \mathrm{c}$ \\
\hline
\end{tabular}

${ }^{1} \mathrm{~A}=$ Cinnamon oil $; \mathrm{B}=$ Clove oil $; \mathrm{C}=$ Lemon oil $; \mathrm{D}=2 \%$ Iodine $+2.4 \% \mathrm{KI}$; $\mathrm{E}=10 \%$ Povidone-iodine; $\mathrm{F}=6 \% \mathrm{NaOCl}$

${ }^{2}$ Values are means $(n=10)$. Means followed by the same letters within the same column are not significantly different at $P=0.05$ by DMRT.

\section{DICUSSIONS}

In the experiment, $10 \%$ povidone-iodine or $6 \%$ sodium hypochlorite or $2 \%$ iodine $+2.4 \%$ potassium iodide at the concentration of $108,36,36 \mu \mathrm{L} / 20 \mathrm{~mL}$ medium, respectively, were promising to use as sterilizing agents in solid MS medium. These disinfectants provided completely sterile condition of MS medium. The disinfectant-treated medium could be used for culturing chrysanthemum shoot and node explants. In vitro plantlets obtained from medium treated with these disinfectants showed similar or better growth than those obtained from autoclaved medium. The results were similar to the reports of Teixeira et al. [5], Yanagawa et al. [6] and Chansean and Syoichi [7]. Culture media, for wild orchid seeds germination, Cymbidium and Phalaenopsis micropropagation, were sterilized by adding sodium hypochlorite at the appropriate concentrations of $0.005 \%$ active chlorine [6], [7]. Teixeira et al. [5] reported that active chlorine at the concentrations of $0.0003 \%$ or $0.0005 \%$ provided completely sterile condition of culture medium for pineapple micropropagation. Moreover, sodium hypochlorite at the concentration of $0.1 \%$ was reported to be used as chemical sterilizing agent of culture medium for sugarcane without autoclaving [3], [25]. Cardoso and Teixeira da Silva
[26] presented the effective chemical sterilization of medium using $0.0025 \%$ chlorine dioxide $\left(\mathrm{ClO}_{2}\right)$ for gerbera micropropagation.

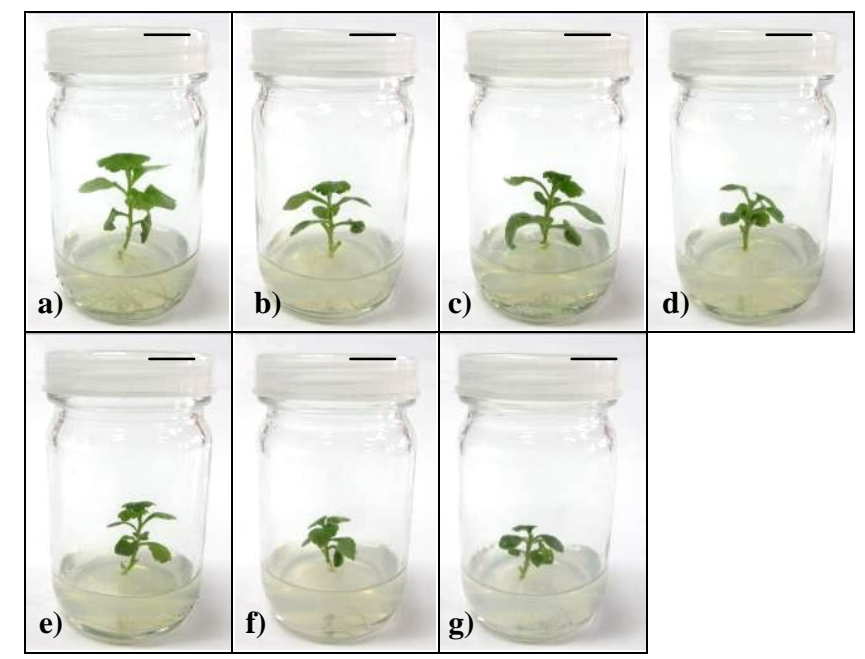

Fig. 1. Growth of chrysanthemum 'Moneymaker Improve' shoot explants on sterilizing agent treated 20-mL MS medium culture for 5 weeks (bar $=1 \mathrm{~cm}$.) a) autoclaved medium; b) $36 \mu \mathrm{L} 2 \%$ Iodine $+2.4 \% \mathrm{KI}$ (D); c) $108 \mu \mathrm{L} 10 \%$ povidone-iodine (E); d) $36 \mu \mathrm{L} 6 \% \mathrm{NaOCl}(\mathrm{F})$; e) $36 \mu \mathrm{L} \mathrm{D}: \mathrm{E}=1: 1$; f) $72 \mu \mathrm{L}$ $\mathrm{D}: \mathrm{E}=1: 3$; g) $108 \mu \mathrm{L} \mathrm{E}:$ Lemon oil $(\mathrm{C})=1: 3$.

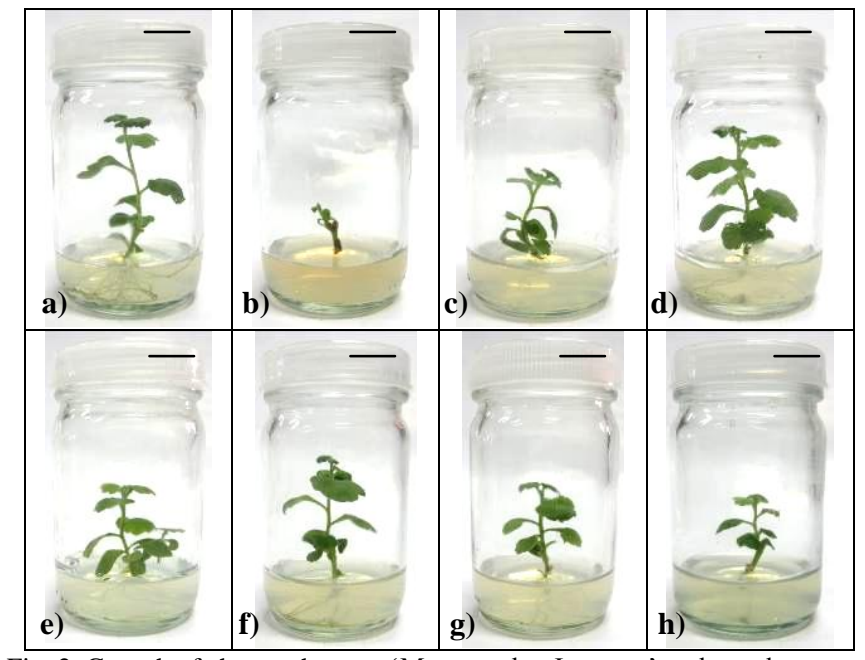

Fig. 2. Growth of chrysanthemum 'Moneymaker Improve' node explants on sterilizing agent treated 20-mL MS medium culture for 5 weeks $(\mathrm{bar}=1 \mathrm{~cm}$.) a) autoclaved medium; b) $9 \mu \mathrm{L}$ clove oil (B); c) $36 \mu \mathrm{L} 2 \%$ iodine $+2.4 \% \mathrm{KI}$ (D); d) $108 \mu \mathrm{L} 10 \%$ povidone-iodine (E); e) $36 \mu \mathrm{L} 6 \% \mathrm{NaOCl}$ (F); f) $36 \mu \mathrm{L}$ $\mathrm{D}: \mathrm{E}=1: 1$; g) $72 \mu \mathrm{L} \mathrm{D}: \mathrm{E}=1: 3$; h) $108 \mu \mathrm{L} \mathrm{E}:$ Lemon oil $(\mathrm{C})=1: 3$.

Essential oils showed antimicrobial activity. Fungicidal efficacy against Rhizoctonia solani, Aspergillus flavus and Fusarium verticillioides was found from betel [16], [17]. Antibacterial activity against some food-borne pathogens, gram negative and/or gram positive bacteria was found from clove [8], betel [15], cassumunar ginger [18], lavender [19, 20], lemon and bergamot [21] and turmeric [22]. In the experiment, cinnamon oil and clove oil at the concentrations of 36 and $18 \mu \mathrm{L} / 20 \mathrm{~mL}$ medium provided completely sterile conditions of MS medium. However, these essential oils were toxic to chrysanthemum shoot and node explants and very poor growth or no survival of explants was found. For combinations of disinfectants and essential oils, it was found that $2 \%$ iodine $+2.4 \% \mathrm{KI}:$ cinnamon oil $(6: 1)$ and $2 \%$ iodine $+2.4 \% \mathrm{KI}$ : clove oil $(6: 1)$ at the concentrations of 
108 and $72 \mu \mathrm{L} / 20 \mathrm{~mL}$ medium gave 100 and $95 \%$ sterile conditions of MS medium, respectively, but no growth of explants was found. However, growth of shoot and node explants was observed from medium treated with $10 \%$ povidone-iodine : lemon oil $(3: 1)$ at the concentration of 108 $\mu \mathrm{L} / 20 \mathrm{~mL}$ medium with $95 \%$ sterile condition of medium.

The report on using disinfections, essential oils and in combinations as sterilizing agents was established to eliminate microorganisms in MS medium to obtain sterile condition without autoclaving. The treated medium could be used for culturing chrysanthemum apical shoots and nodes. However, further experiments are needed to establish appropriate concentrations of single essential oil or various combinations as sterilizing agents in MS medium used for plant tissue culture.

\section{CONCLUSIONS}

Disinfectants, $10 \%$ povidone-iodine or $2 \%$ iodine $+2.4 \%$ potassium iodide, at the appropriate concentrations (108 $\mu \mathrm{L} / 20 \mathrm{~mL}$ medium and $36 \mu \mathrm{L} / 20 \mathrm{~mL}$ medium, respectively), were effective for eradicate microorganisms, causal agents of in vitro contamination, and provided completely sterile conditions of solid MS medium without autoclaving. MS medium treated with these sterilizing agents could be used for culturing chrysanthemum 'Moneymaker Improved' shoots and nodes. For essential oil alone added in MS medium, no growth of chrysanthemum shoot and node explants was found and explants died eventually. However, growth of explants was observed from medium added with $10 \%$ povidone-iodine in combination with lemon oil (ratio 3 : 1) at the concentration of $108 \mu \mathrm{L} / 20 \mathrm{~mL}$ medium) that provided $95 \%$ sterile condition of MS medium.

\section{ACKNOWLEDGEMENTS}

This research was financial supported by Thailand Toray Science Foundation (TTSF) and Faculty of Science, Silpakorn University, Thailand.

\section{REFERENCES}

[1] A. D. Russell, "Similarities and differences in the responses of microorganisms to biocides," J. Antimicrob. Chemoth, vol. 52, no. 5, pp. 750-763, 2003.

[2] United State Patent 5750402. Compositions and methods to prevent microbial contamination of plant tissue culture media. [Online]. Available: http://www. freepatentonline.com/ 5750402.html.

[3] R. A. Sawant and P. N. Tawar, "Use of sodium hypochlorite as media sterilant in sugarcane micropropagation at commercial scale," Sugar Tech., vol. 13, no. 1, pp. 27-35, 2011.

[4] U. Habiba, S. Reza, M. L. Saha, M. R. Khan, and S. Hadiuzzaman, "Endogenous bacterial contamination during in vitro culture of table banana: Identification and prevention," Plant Tissue Cult, vol. 12, no. 2 pp. 117-124, 2002.

[5] S. L. Teixeira, "The development of a new protocol that uses sodium hypochlorite to replace the autoclaving procedure for establishing axenic in vitro banana (Musa sp.) culture," Agricell Report, vol. 47, no. 3, pp. 17-18, 2006.

[6] T. Yanagawa, M. Nagai, T. Ogino, and M. Maeguchi, "Application of disinfection to orchid seeds, plantlet and media as a means to prevent in vitro contamination," Lindleyana, vol. 10, pp. 33-36, 2006.

[7] M. Chansean and I. Syoichi, "Conservation of wild Orchids in Cambodia by Simple Ase ptic Culture Method," in Proc. NIOC, April, 2007, pp. 13-19.

[8] B. Joshi, G. P. Sah, B. B. Basnet, M. R. Bhatt, D. Sharma, K. Subedi, J. Pandey, and R. Malla, "Phytochemical extraction and antimicrobial properties of different medicinal plants: Ocimum sanctum (tulsi), Eugenia caryophyllata (clove), Achyranthes bidentata (datiwan) and Azadirachta indica (neem)," Journal of Microbiology and Antimicrobials, vol. 3, no. 1, pp. 1-7, January, 2011.

[9] L. Nunez, M. D. Aquino, and J. Chirife, "Antifungal properties of clove oil (Eugenia caryophylata) in sugar solution,” Braz. J. Microbiol, vol. 32, pp. 123-126, 2001.

[10] F. G. Kirbaslar, A. Tavman, B. Dulger, and G. Turker, "Antimicrobial activity of Turkish Citrus peel oils," Pak. J. Bot., vol. 41, pp. 3207-3212, 2009.

[11] M. J. Dhanavade, C. B. Jalkute, J. S. Ghosh, and K. D. Sonawane. "Study antimicrobial activity of lemon (Citrus limon L.) peel extract," Br. J. Pharmacol. Toxicol., vol. 2, no. 3, pp. 119-122, 2011.

[12] L. B. Gende, I. Floris, R. Fritz, and M. J. Eguaras, "Antimicrobial activity of cinnamon (Cinnamomum zeylanicum) essential oil and its main components against Paenibacillus larvae from Argentine," B. Insectol, vol. 61, no. 1, pp. 1-4, 2008.

[13] M. Usha, S. Ragini, and S. M. A. Naqvi. "Antibacterial activity of acetone and ethanol extracts of cinnamon (Cinnamomum zeylanicum) and ajowan (Trachyspermum ammi) on four food spoilage bacteria," International Research Journal of Biological Sciences, vol. 1, no. 4, pp. 7-11, August, 2012.

[14] S. Ranjan, N. Dasgupta, P. Saha, M. Rakshit, and C. Ramalingam. "Comparative study of antibacterial activity of garlic and cinnamon at different temperature and its application on preservation of fish," Advances in Applied Science Research, vol. 3, no. 1, pp. 495-501, 2012.

[15] M. M. Hoque, S. Rattila, M. A. Shishir, M. L. Bari, Y. Inatsu, and S. Kawamoto, "Antibacterial activity of ethanol extract of betel leaf (Piper betle L.) against some food borne pathogens," Bangladesh $J$. Microbiol., vol. 28, no. 1, pp. 58-63, 2011.

[16] M. Seema, S. S. Sreenivas, N. D. Rekha, and N. S. Devaki, "In vitro studies of some plant extracts against Rhizoctonia solani Kuhn infecting FCV tobacco in Karnataka Light Soil, Karnataka, India,' Journal of Agricultural technology, vol. 7, no. 5, pp. 1321-1329, 2011.

[17] D. Srichana, A. Phumruang, and B. Chongkid, "Inhibition effect of betel leaf extract on the growth of Aspergillus flavus and Fusarium verticillioides," Thammasat Int. J. Sc. Tech., vol. 14, no. 3, pp. 74-77, 2009.

[18] T. S. A. T. Kamazeri, O. A. Samah, M. Taher, D. Susanti, and H. Qaralleh, "Antimicrobial activity and essential oils of Curcuma aerugonosa, Curcuma mangga and Zingiber cassumunar from Malaysia," Asian Pac. J. Trop. Med., vol. 5, no. 3, 202-209, March, 2012.

[19] I. N. Fit, G. Rapuntean, S. Rapuntean, F. Chirila, and G. C. Nadas, "Antibacterial effect of essential essential vegetal extracts on Staphylococcus aureus compared to antibiotics," Not. Bot. Horti. Agrobo., vol. 37, 117-223, 2009.

[20] L. Hui, L. He, L. Huan, L. Xiaolan, and Z. Aiguo, "Chemical composition of lavender essential oil and its antioxidant activity and inhibition against rhinitis related bacteria," Afr. J. Microbiol. Res., vol. 4, pp. 309-313, 2010.

[21] F. G. Kirbaslar, A. Tavman, B. Dulger, and G. Turker, "Antimicrobial activity of Turkish Citrus peel oils," Pak. J. Bot., vol. 41, pp. 3207-3212, 2009.

[22] S. S. Allawi, J. M. Auda, H. Q. Hameed, and T. I. Ali, "The effect of Curcuma longa (turmeric) rhizomes extracts on pathogenic bacteria in comparison with standard antibiotics," Journal of Biotechnology Research Center, vol. 3, no. 1, pp. 15-20, 2009.

[23] T. Murashige and F. Skoog, "A revised medium for rapid growth and bioassays with tobacco tissue culture," Physiol. Plantarum, vol. 15, no. 3, pp. 473-497, 1962.

[24] D. B. Duncan, "Multiple range and multiple F test," Biometrics, vol. 11, pp. 1-42, 1995.

[25] A. K. Tiwari, S. Tripathi, and M. Lal, "Screening of some chemical disinfectants for media sterilization during" Vitro micropropagation of sugarcane. Sugar Tech., vol. 14, no. 4, pp. 364-369, 2012.

[26] J. C. Cardoso and J. A. T. da Silva, "Micropropagtion of gerbera using chlorine dooxide $\left(\mathrm{ClO}_{2}\right)$ to sterile the culture medium," Vitro Cellular \& Developmental Biology-Plant, vol. 48, pp. 362-368, 2012.

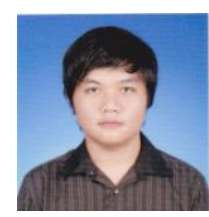

Wittaya Deein was born in 1989. He is a graduate student at the Biology Department, Faculty of Science, Silpakorn University, Nakhon Pathom. His research of interest is plant tissue culture of economic plants. 


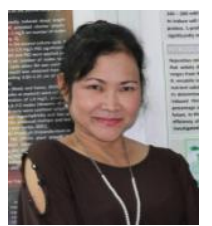

Chockpisit Thepsithar was born in 1959. She obtained $\mathrm{PhD}$ in Agri\&Nat Res Sci (Horticulture) from The University of Adelaide, Australia. Her researches of interest are tissue culture of economic plants and sterilization of plant tissue culture media without autoclaving.

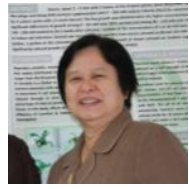

Aree Thongpukdee was born in 1953. She obtained PhD in botany from The University of Queensland, Australia. Her researches of interest are plant taxonomy of flowering plants emphasizing on Solanaceae and plant tissue culture of economic plants.

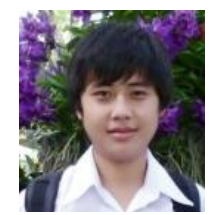

Suppaya Tippornwong was born in 1988 . He is an undergraduate student at the Biology Department, Faculty of Science, Silpakorn University, Nakhon Pathom. Her research of interest is plant tissue culture. 